Table 1. Patient characteristics with RF and ACPA positivity

\begin{tabular}{|c|c|c|c|c|c|c|}
\hline & $\begin{array}{c}\text { RF positive } \\
(n=11477)\end{array}$ & $\begin{array}{l}\text { RF negative } \\
(\mathrm{n}=115995)\end{array}$ & $\mathrm{p}$ value & $\begin{array}{l}\text { ACPA positive } \\
\quad(n=21)\end{array}$ & $\begin{array}{l}\text { ACPA negative } \\
\quad(n=1646)\end{array}$ & $\begin{array}{c}\mathrm{p} \\
\text { value }\end{array}$ \\
\hline Age & $\begin{array}{r}44.86 \\
(12.32)\end{array}$ & 44.94 (12.47) & 0.54 & $37.90(9.07)$ & $45.26(12.58)$ & 0.008 \\
\hline Male (\%) & 5659 (49.3) & $57309(49.4)$ & 0.845 & $11(52.4)$ & $834(50.7)$ & 1 \\
\hline Body Mass Index & 22.33 (3.38) & $22.35(3.40)$ & 0.521 & $21.64(3.28)$ & $22.34(3.37)$ & 0.346 \\
\hline Smoker, total (\%) & 4509 (39.3) & $45738(39.4)$ & 0.772 & $12(57.1)$ & $642(39.0)$ & 0.115 \\
\hline Current smoker (\%) & $1959(17.1)$ & $20483(17.7)$ & 0.114 & $8(38.1)$ & $277(16.8)$ & 0.017 \\
\hline Previous smoker (\%) & $2550(22.2)$ & 25255 (21.8) & 0.271 & $4(19.0)$ & $365(22.2)$ & 1 \\
\hline Brinkman index & $144.8(299.3)$ & $145.2(313.8)$ & 0.897 & $280.9(409.7)$ & $145.3(300.3)$ & 0.041 \\
\hline $\begin{array}{l}\text { Number of ciga- } \\
\text { rettes (/day) }\end{array}$ & $17.7(18.5)$ & $17.4(13.3)$ & 0.166 & $19.8(12.0)$ & $17.4(12.1)$ & 0.511 \\
\hline $\begin{array}{l}\text { Smoking Duration } \\
\text { (years) }\end{array}$ & $7.43(11.68)$ & 7.45 (11.66) & 0.851 & $13.33(14.11)$ & 7.49 (11.68) & 0.023 \\
\hline Alcohol Drinker (\%) & $6972(60.7)$ & $0.4)$ & 0.418 & $10(4$ & $1005(61.1)$ & 0.261 \\
\hline $\begin{array}{l}\text { Alcohol Intake (g/ } \\
\text { day) }\end{array}$ & $13.67(21.88)$ & $13.58(21.32)$ & 0.676 & $16.70(26.89)$ & $14.06(22.16)$ & 0.59 \\
\hline $\begin{array}{c}\text { Exercise } \geqq 3 \text { times/ } \\
\quad \text { week }(\%)\end{array}$ & $2792(24.3)$ & $28293(24.4)$ & 0.882 & $5(23.8)$ & $402(24.4)$ & 1 \\
\hline $\begin{array}{l}\text { White blood cell } \\
(103 / \mu \mathrm{L})\end{array}$ & $5.32(1.46)$ & $5.35(1.50)$ & 0.13 & $5.59(2.05)$ & $5.37(1.54)$ & 0.52 \\
\hline Hemoglobin (g/dL) & $13.82(1.44)$ & $13.82(1.45)$ & 0.753 & $14.12(1.03)$ & $13.83(1.43)$ & 0.36 \\
\hline Creatinine $(\mathrm{mg} / \mathrm{dL})$ & $0.73(0.20)$ & $0.73(0.25)$ & 0.194 & $0.76(0.16)$ & $0.73(0.18)$ & 0.586 \\
\hline AST (U/L) & 21.89 (9.39) & 21.93 (11.65) & 0.782 & $20.95(6.02)$ & $21.68(8.29)$ & 0.69 \\
\hline $\begin{array}{l}\text { LDL cholesterol } \\
(\mathrm{mg} / \mathrm{dL})\end{array}$ & $\begin{array}{l}115.41 \\
(30.90)\end{array}$ & $115.48(30.77)$ & 0.815 & $112.62(33.26)$ & 115.36 & 0.688 \\
\hline Triglyceride (mg/dL) & $97.63(78.46)$ & $97.70(80.36)$ & 929 & $\begin{array}{l}100.57 \\
(63.40)\end{array}$ & $3.37)$ & 0.874 \\
\hline Uric Acid (mg/dL) & $5.32(1.42)$ & $5.33(1.42)$ & 0.623 & $5.76(1.34)$ & $5.34(1.42)$ & 0.172 \\
\hline
\end{tabular}

Disclosure of Interests: None declared

DOI: 10.1136/annrheumdis-2020-eular.4134

\section{AB0199 GENES PREDICTIVE ON THE EFFICACY OF INFLIXIMAB IN THE TREATMENT OF RHEUMATOID ARTHRITIS: A PROSPECTIVE, MULTI-CENTRE, CLINICAL PERFORMANCE EVALUATION STUDY FOR AN IN-VITRO DIAGNOSTICS MEDICAL DEVICE}

E. Kiss ${ }^{1}$, G. Poór ${ }^{1}$, G. Zahuczky ${ }^{2}$, K. Tauberné Jakab ${ }^{3}$, M. Sebeszta ${ }^{3}$, T. Ponyi ${ }^{3}$, Z. Hollo' ${ }^{3} .{ }^{1}$ National Rheumatology and Physiotherapy Institute, Budapest, Hungary; ${ }^{2} U D$-GenoMed Medical Genomic Technologies Ltd, Debrecen, Hungary; ${ }^{3}$ Egis Pharmaceuticals PLC, Budapest, Hungary

Background: Approximately $30 \%$ of rheumatoid arthritis (RA) patients fail to respond to first biological therapy, thus treatment selection of biologic therapy for patients with RA is of high importance. The lack of biomarkers to predict specific biological treatment response, in the case of non-responder (NR) patients leads to unnecessary exposure, delay of adequate therapy, progression of the disease and therapy cost increase. Predicting the patient's responsiveness to the first biological therapy is still an unmet need in the clinical setting. Predictive in vitro testing would have a significant effect on the administration of biological therapy, on the real life implementation of cost effective personalized therapy.

Objectives: The purpose of this in vitro diagnostic medical device study was to demonstrate that particular gene expression profiles as genomic biomarkers (i.e. the IVD medical device) predict therapeutic response to infliximab, discriminate between responders and non-responders to infliximab treatment. Responders were defined if they reached DAS target value DAS28 $\leq 3.2$ at 6 month (M6).

Methods: 110 bionaive patients were enrolled with moderate-high activity RA (DAS28-CRP >3.2), who have responded inadequately to DMARDs (including methotrexate), after they have been assigned to infliximab treatment. All patients received commercially available infliximab, procured according to SmPC, local guidelines and regulations in this non-interventional clinical study. The clinical response was evaluated according to the change from baseline in disease activity at M6. Clinical characteristics (RA duration, smoke, steroid treatment, etc.) and serological parameters (RF, ACPA, aCVM) were collected. A $3^{\text {rd }}$ visit scheduled around week 22 (M6) and change of DAS28-CRP value from the baseline has been evaluated. Gene expression profiling was performed from blood samples taken at month 0 (M0); - just before the first infliximab infusion. Global gene expression profiling was performed to identify differentially expressing genes using RNA sequencing. The set of differentially expressing genes were further reduced with a combination of machine learning modelling and various feature elimination methods. The expression of the reduced gene set was confirmed and further analysed using reverse-transcription and quantitative real-time PCR.
Results: A total of 250 genes were identified by a combination of differential gene expression analyses, feature elimination techniques and various machine learning modelling methods of which 44 genes showed significant differences between NR and good responder groups. Preliminary interim analysis identified associations between gene expression and clinical response/ non-response to infliximab therapy.

Table. Three models containing gene expression + clinical data sets illustrates some statistical characteristics

\begin{tabular}{lrrrrrrr}
\hline $\begin{array}{l}\text { Modell } \\
\text { building_ID }\end{array}$ & \multicolumn{3}{c}{ Accuracy Sensitivity Specificity $\begin{array}{l}\text { Modell } \\
\text { Verification }\end{array}$} \\
\hline 00232 & 100.00 & 100.00 & 100.00 & 00232 & 88 & 88.89 & 87.50 \\
00249 & 98.82 & 96.55 & 100.00 & 00249 & 84 & 77.78 & 87.50 \\
00270 & 98.82 & 96.55 & 100.00 & 00270 & 88 & 77.78 & 93.75
\end{tabular}

Conclusion: Our preliminary analysis shows that this set of genes and selected clinical parameters are predictive markers for infliximab specific response in RA patients. Ongoing work involves the clinical validation of these results in an independent patient cohort $(n=60)$. This approach provides the opportunity to develop an in vitro diagnostic test method for the prediction of infliximab treatment responsiveness in bionaive rheumatod arthritis patients, hence to personalize infliximab therapy for these patients.

Disclosure of Interests: Emese Kiss Consultant of: EK has received consultancy fees from Egis., Gyula Poór Consultant of: GyP has received consultancy fees from Egis and he was the coordinating investigator in this study, Gábor Zahuczky Grant/research support from: Egis, Katalin Tauberné Jakab Employee of: Egis., Miklós Sebeszta Employee of: Egis., Tamás Ponyi Employee of: Egis. Zsolt Holló Employee of: Egis.

DOI: 10.1136/annrheumdis-2020-eular.5849

\section{AB0200 1 SHORT AND MID-TERM OUTCOME OF FOREFOOT SURGERY FOR PATIENTS WITH RHEUMATOID ARTHRITIS}

\section{R. Kurose ${ }^{1} .{ }^{1}$ Hirosaki Memorial Hospital, Hirosaki, Japan}

Background: Patients with rheumatoid arthritis (RA) have frequently painful foot deformities. These deformities including hallux valgus, dorsal dislocation of the metatarsophalangeal (MTP) joints and hammer toe deformity of the lesser toes are associated with disability in daily activities.

Objectives: The aim of this study is to investigate short and mid-term outcome of forefoot surgery for patients with RA.

Methods: We investigated 28 patients with 39 foots who underwent forefoot surgery between January 2010 and December 2018 and followed for more than one year after surgery. Swanson implant arthroplasty or metatarsal osteotomy was performed for big toe, and shortening oblique osteotomy (SOO) was performed for the II-V toes. Examination items were as follows; plain X-ray changes in the angle of hallux valgus (HVA), the angle between the first and second metatarsal bones (M1/2), and the angle between the first and fifth metatarsal bones (M1/5) after surgery. The progress of painful hyperkeratosis and bunion, Japanese Society for Surgery of the foot standard rating system (JSSF scale), the recurrence of deformity and bone fusion, complications, and patient satisfaction were also examined. Results: The patients followed were 24 women with 34 feet and 4 men with 5 feet, and average age at the time of surgery was 66.1 years. HVA improved from average of 39.7 degrees to 20.2 degrees one month after surgery, but increased slightly to 23.5 degrees one year after surgery. Painful hyperkeratosis and bunion tended to disappear one month after surgery, and JSSF scale significantly improved at the final observation. One year after surgery, the bone fusion rate of big toe was $100 \%$, but $7.8 \%$ of the metatarsal bone underwent SOO had non-union. The complications after surgery were one infection at the surgical site, one necrosis at the tip of the toe, and one infection of Swanson implant. Patient satisfaction at the final observation was high

Conclusion: Forefoot surgery for RA has problems such as recurrence, non-union, and infections, but it is considered to be a useful treatment because that pain by hyperkeratosis and bunion disappears and ADL improves.

References:

[1] Sung IH, Sung YK, Huh DR, Kim SJ. A comparative study on the results of the modified Ludloff osteotomy for hallux valgus deformities with minimal erosion of the metatarsophalangeal joints in rheumatoid patients versus non-rheumatoid patients.. Mod Rheumatol 2015; 25(5): 694-700.

Disclosure of Interests: None declared

DOI: 10.1136/annrheumdis-2020-eular.5023 